Wioleta Kilar, SŁawomir Kurek, Tomasz Rachwat, Marcin Semczuk, Agnieszka Świętek Uniwersytet Pedagogiczny w Krakowie, Polska - Pedagogical University of Cracow, Poland

\title{
Kształtowanie postaw przedsiębiorczych z uwzględnieniem zasad ekorozwoju wśród uczniów z wykorzystaniem gry PowerPlayer wypracowanej w ramach projektu SUSEN
}

\author{
Development of Entrepreneurial Attitudes with Regard to the Principles \\ of Sustainable Development Among Pupils Using the PowerPlayer Game Developed \\ Within the Project SUSEN
}

Streszczenie: Przedsiębiorczość w europejskim systemie edukacji jest postrzegana jako kompetencja kluczowa, której kształtowanie wpływa także na rozwój innych ważnych kompetencji w procesie kształcenia przez całe życie. Dlatego cele kształcenia w zakresie przedsiębiorczości, w szczególności w ramach edukacji szkolnej, są szerokie i nie odnoszą się tylko do wiedzy i umiejętności potrzebnych do założenia i prowadzenia własnej działalności gospodarczej. Jednocześnie jednym z wielkich wyzwań cywilizacyjnych jest realizacja strategii zrównoważonego (ang. sustainable) rozwoju, a edukacja na rzecz zrównoważonego rozwoju jest jednym z głównych filarów tej strategii. Do tych szczególnych wyzwań edukacyjnych nawiązuje Europejski projekt SUSEN (ang. „Sustainable Entrepreneurship - A Game-Based Exploration for Lower Secondary Schools”, tj. „Zrównoważona przedsiębiorczość - odkrywanie idei z wykorzystaniem gry dla szkół gimnazjalnych") realizowany przez konsorcjum składające się z partnerów z różnych krajów europejskich. Przedmiotem pracy są przesłanki realizacji, podstawowe cele i produkty finalne tego projektu, przydatne w edukacji w zakresie przedsiębiorczości i ekorozwoju. Podstawowym celem artykułu jest pokazanie możliwości i zalet zastosowania w praktyce edukacyjnej głównego produktu, którym jest gra dydaktyczna PowerPlayer, oraz ocena jego przydatności w świetle wstępnych wyników pilotażu prowadzonego w polskich szkołach. PowerPlayer to gra planszowa przeznaczona dla uczniów, głównie wieku w wieku 12-15 lat. Narzędzie to łączy w sobie cechy typowe dla gier strategicznych z elementami edukacyjnymi. Gra ma na celu wprowadzenie koncepcji „zrównoważonej” przedsiębiorczości w atrakcyjnej formie dla uczniów ostatniej klasy szkół podstawowych i szkół gimnazjalnych, którzy w jej trakcie podejmują decyzje biznesowe w zakresie wykorzystania źródeł energii. Gra łączy zatem tradycyjne poznawanie treści na lekcji z praktycznymi ćwiczeniami, dzięki czemu uczenie się staje się bardziej efektywne. W ramach pakietu dostarczane są także ciekawe studia przykładowe z życia gospodarczego, pokazujące, jak firmy wiążą w praktyce myślenie biznesowe (nakierowane na efektywność ekonomiczną) z dbałością o środowisko w zakresie wykorzystania źródeł energii. Wstępne wyniki pilotażowe badań w Polsce wskazują na atrakcyjność gry i jej przydatność w praktyce szkolnej.

Abstract: Entrepreneurship in the European education system is treated as a key competence, which also influences the development of other key competences for lifelong learning. Therefore, the objectives 
of entrepreneurship education, especially in the context of school education, are broad and do not refer only to the knowledge and skills needed to set up and conduct own business. At the same time, one of the great challenges of civilization is the implementation of strategies for sustainable development, which is why education for sustainable development is one of the main pillars of this strategy. For these particular educational challenges the European project SUSEN ("Sustainable Entrepreneurship - A Game-Based Exploration for Lower Secondary Schools"), was established and implemented by a consortium of partners from different European countries. The subject of the paper is the rationale, the basic objectives and the final products of this project, useful in entrepreneurship education and sustainability. The main aim of this article is to show the possibility and advantages of applying in practice the educational main product, which is a learning game Power Player and assess its suitability in the light of the preliminary results of the pilot project conducted in Polish schools. This is a board game for students, mostly aged between 12-15 years. This tool combines the features of a typical strategy game with elements of education. The game aims to introduce the concept of sustainable business in an attractive form for pupils of the final class of primary and lower-secondary schools (gymnasium), by making business decisions in the use of energy sources. The game thus combines traditional learning content for lessons with practical exercises, so that learning becomes more effective. The project is also supplied with the interesting case studies of economic life, showing in practice how companies combine business thinking (focused on economic efficiency) with care for the environment in the use of energy sources. Preliminary results of pilot studies in Poland indicate its attractiveness and usefulness in school practice.

Słowa kluczowe: edukacja w zakresie przedsiębiorczości; ekorozwój; gimnazjum; gra edukacyjna; rozwój zrównoważony; szkoła podstawowa; źródła energii

Key words: eco-development; educational game; energy sources; entrepreneurship education; primary school; secondary school; sustainable development

Otrzymano: 21 grudnia 2015

Received: 21 December 2015

Zaakceptowano: 31 maja 2016

Accepted: 31 May 2016

\section{Sugerowana cytacja/Suggested citation:}

Kilar, W., Kurek, S., Rachwał, T., Semczuk M., Świętek A. (2016). Kształtowanie postaw przedsiębiorczych z uwzględnieniem zasad ekorozwoju wśród uczniów z wykorzystaniem gry PowerPlayer wypracowanej w ramach projektu SUSEN. Przedsiębiorczość - Edukacja, 11, 444-456.

\section{Wstęp}

Dynamicznie zmieniające się uwarunkowania rozwoju społeczno-gospodarczego sprawiają, że niezwykle ważna jest znajomość zasad funkcjonowania przedsiębiorstw oraz procesów gospodarczych dokonujących się w ich otoczeniu. Dużą rolę w tym zakresie odgrywa odpowiednie przygotowanie społeczeństwa do funkcjonowania w coraz bardziej złożonych systemach społecznych, gospodarczych i kulturowych w toku edukacji szkolnej i procesu kształcenia przez całe życie (por. Zioło, 2012). Szczególną funkcję pełni tu edukacja ekonomiczna, zwłaszcza lekcje z zakresu przedsiębiorczości, które powinny starannie przygotować ucznia do radzenia sobie w codziennych i nadzwyczajnych, łatwych i trudnych sytuacjach, z którymi zetknie się w toku dalszej edukacji i w życiu zawodowym. Zwrócił na to uwagę K. Wach (2013), stwierdzając, iż celem edukacji dla przedsiębiorczości, obejmującej przekazywanie wiedzy, nabywanie umiejętności oraz kształtowanie postaw, jest krzewienie przedsiębiorczości w życiu osobistym, społecznym i zawodowym uczniów, w efekcie czego kształtują oni swoją 
przedsiębiorczość osobowościową, przejawiającą się w proaktywności i innowacyjności, gotowości na zmiany oraz działaniu, czyli aktywnej inicjatywności. Sprzyjać temu powinni kompetentni i dobrze przygotowani nauczyciele, będący wzorem dla uczniów, którzy inspirują do uczenia się (por. Żur, 2014) i kształtują postawy przedsiębiorcze zarówno przez zajęcia lekcyjne prowadzone w ciekawy sposób, jak i przez aktywną postawę wobec otaczającego ich świata. Kluczową sprawą jest tutaj zastosowanie odpowiednich metod dydaktycznych, wśród których ważną rolę odgrywają metody aktywizujące, w tym wykorzystujące gry edukacyjne i studia przykładowe.

Do tych szczególnych wyzwań edukacyjnych nawiązuje europejski projekt SUSEN (ang. „Sustainable Entrepreneurship - A Game-Based Exploration for Lower Secondary Schools”, tj. „Zrównoważona przedsiębiorczość - odkrywanie idei z wykorzystaniem gry dla szkół gimnazjalnych”) realizowany przez konsorcjum składające się z partnerów z krajów europejskich: Uniwersytet Pedagogiczny im. Komisji Edukacji Narodowej w Krakowie - Instytut Geografii, Zakłady: Przedsiębiorczości i Gospodarki Przestrzennej, Geografii Społeczno-Ekonomicznej, Dydaktyki Geografii (Polska); Uniwersytet Koblenz-Landau (Niemcy) - lider projektu, Environmental; Academy, a od 2017 r. University College of London (Wielka Brytania), CVO Antwerpen (Belgia), Uniwersytet Pedagogiczny w Freiburgu (Niemcy) oraz Associazione Seed (Szwajcaria). Przedmiotem pracy są przesłanki realizacji, podstawowe cele i produkty finalne tego projektu, przydatne w edukacji w zakresie przedsiębiorczości i ekorozwoju. Podstawowym celem artykułu jest pokazanie możliwości i zalet zastosowania w praktyce edukacyjnej głównego produktu, którym jest gra dydaktyczna PowerPlayer, zakładanych efektów kształcenia oraz ocena jego przydatności w świetle wstępnych wyników pilotażu prowadzonego w polskich szkołach. W artykule zmierzać będzie się także do przedstawienia zalet zastosowania gier dydaktycznych na podstawie literatury przedmiotu oraz możliwości integracji gry z poszczególnymi przedmiotami szkolnymi na podstawie wyników analizy zapisów podstawy programowej kształcenia ogólnego. PowerPlayer jest grą planszową przeznaczoną dla uczniów na II i III etapie edukacyjnym, głównie w wieku 12-15 lat (ze względu na różnice w systemach edukacyjnych poszczególnych krajów przyjęto, że w Polsce grupą docelową będą uczniowie 6 klasy szkoły podstawowej oraz uczniowie wszystkich klas gimnazjum). W artykule dokonano charakterystyki gry, przedstawiono zakładane cele dydaktyczne (efekty kształcenia) i możliwości realizacji w ramach poszczególnych zajęć, a także wstępne wyniki pilotażowe testów przeprowadzonych w 4 polskich szkołach ${ }^{1}$, które miały na celu zbadanie atrakcyjności gry i jej przydatność w praktyce szkolnej. Gra była przedmiotem pilotażu w następujących szkołach: KOSTKA Publiczne Gimnazjum Jezuitów im. Św. Stanisława Kostki w Krakowie; Zespół Szkół Ogólnokształcących Integracyjnych Nr 6 w Krakowie - Szkoła Podstawowa nr 98 - oraz Gimnazjum nr 74; Szkoła Podstawowa nr 16 im. W. Broniewskiego w Rzeszowie. W sumie pilotażem objęto 4 nauczycieli tych szkół i 76 uczniów.

\section{Rola gier dydaktycznych i studium przypadku w edukacji w zakresie przedsiębiorczości}

Jedną z metod wykorzystywanych w skutecznym i atrakcyjnym kształceniu są gry dydaktyczne różnego typu. Wspomagają one proces kształcenia przedsiębiorczości, gdyż zmuszają

\footnotetext{
${ }^{1}$ Zgodnie z założeniami projektu, partnerzy z czterech krajów (Polska, Belgia, Niemcy, Wielka Brytania) mają przetestować grę w co najmniej trzech szkołach. W okresie przygotowywania ostatecznej wersji publikacji pilotaż gry był zakończony w Polsce, dlatego można przedstawić pierwsze wnioski.
} 
ucznia do myślenia i zdobywania wiedzy ekonomicznej. Gry edukacyjne zwykle są oparte na modelach prawdziwych sytuacji ekonomicznych, dlatego wyzwania, przed którymi zostaje postawiony uczeń, są realne i niekiedy dość trudne (Szmulczyńska, 2007).

Ponadto należy zwrócić uwagę, że zgodnie z doświadczeniem nauczycieli i wynikami badań naukowych, problemem w edukacji jest nie tylko zawartość nauczanych treści, ale również wykorzystywanie bardziej efektywnych metod nauczania (por. Tracz, Rachwał, 2008). Niezwykle skutecznym narzędziem w tym zakresie są właśnie gry, gdyż prócz omówionych cech, pozwalają na połączenie nauki i zabawy, zwiększają zaangażowanie uczniów bądź studentów w naukę i pozwalają na eksperymentowanie z różnymi aspektami nauczania. Gra w nauczaniu przedsiębiorczości zmusza uczestników do podejmowania sekwencyjnych decyzji w kolejnych rundach oraz pozwala metodą prób i błędów dokonać grającym głębszej refleksji nad problemami pojawiającymi się np. podczas zarządzania przedsiębiorstwem. Ta forma nauczania nie tylko dostarcza uczniom wiedzy, ale również rozwija ich umiejętności, takie jak zdolność do pracy zespołowej, umiejętność podejmowania decyzji czy zdolności analityczne (Gaweł, Pietrzykowski, 2014; Gaweł, 2014). M. i P. Bołtuć (2004) podkreślają natomiast trzy podstawowe funkcje gier w edukacji:

1. gry motywują użytkownika, stanowiąc atrakcyjne tło psychologiczne nauczania. Jest to szczególnie pomocne młodym ludziom, którzy bardziej identyfikują się emocjonalnie z grami niż z tradycyjnym procesem edukacji;

2. gry symulują realne sytuacje - mogą imitować doświadczenie i dostarczać wielu umiejętności w kontekście praktycznym, nawet jeśli stworzenie takiego kontekstu w rzeczywistości byłoby niebezpieczne lub skomplikowane;

3. gry ułatwiają zoperacjonalizowanie pewnych struktur teoretycznych, przykładowo matematycznych algorytmów, dzięki intuicyjnym środkom strategii pochodzącej z gier.

Autorzy ci podkreślają także, że gracz ma możliwość bardziej aktywnego uczestnictwa w procesie edukacyjnym niż osoba ucząca się w systemie tradycyjnym (Bołtuć, M., Bołtuć P., 2004). Inni autorzy (np. Bernatowicz, Rataj, 2015; Markowski, Pietralczyk, 2013; Pivec, Dziabenko, 2004; Rzepka, 2014) również wskazują na wybranych przykładach korzyści z wykorzystania gier w procesie edukacji ekonomicznej. J. Cewińska i A. Krasnova (2014) zwracają jednak uwagę, że choć obecnie podkreśla się znaczenie gier jako alternatywy dla tradycyjnych metod kształcenia, to ich wykorzystanie w procesie edukacji niesie pewne ograniczenia lub nawet zagrożenia. Warto to mieć na uwadze i nie traktować gier jako jedynej, czy nawet wiodącej metody (techniki) nauczania.

Inną ważną w kształceniu przedsiębiorczości metodą jest studium przypadku (przykładowe; ang. case study), gdyż jak wskazują badania, jest najskuteczniejszą metodą dydaktyczną przygotowującą do przyszłej kariery i rozwijającą praktyczne umiejętności przydatne w dzisiejszym otoczeniu. Dzieje się tak ze względu na to, że analiza przypadku umożliwia uczniom przyjrzenie się sytuacjom biznesowym z różnych perspektyw kulturowych i ekonomicznych, otwierając ich umysły przez oferowanie możliwości rozwiązywania problemów opartych na rzeczywistych sytuacjach biznesowych.

Studium przypadku jest używane podczas kształcenia w zakresie przedsiębiorczości podczas:

- odnoszenia teorii do praktyki,

- rozwijania umiejętności analizowania sytuacji,

- oceniania alternatywnych rozwiązań pod względem ilościowym i jakościowym,

- wykorzystywania intuicji przy podejmowaniu decyzji, 
- rozwijania krytycznego myślenia,

- myślenia dzięki zadawaniu rozważnych pytań,

- uczenia się, jak czerpać wiedzę z własnych doświadczeń,

- rozwijania analizy i syntezy,

- konfrontowania się z zawiłościami konkretnych sytuacji,

- rozwijania umiejętności podejmowania decyzji,

- nabywania umiejętności pozwalających na radzenie sobie w zmieniającym się otoczeniu,

- rozwijania samoanalizy, postaw, pewności siebie i odpowiedzialności,

- rozwijania umiejętności interpersonalnych, komunikacyjnych i umiejętności słuchania,

- rozwijania rozwagi i mądrości przez atrakcyjne formy nauczania,

- przekonującego komunikowania się,

- przekonywania za pomocą argumentacji,

- wyciągania wniosków (Škudienė, 2012).

\section{Charakterystyka gry PowerPlayer jak głównego produktu projektu SUSEN}

Omawiana w niniejszym artykule gra PowerPlayer łączy w sobie cechy typowe dla gier strategicznych $\mathrm{z}$ elementami edukacyjnymi i ma na celu wprowadzenie koncepcji „Zrównoważonej” przedsiębiorczości w atrakcyjnej dla uczniów formie, przez umożliwienie im podejmowania decyzji biznesowych w zakresie wykorzystania źródeł energii zarówno odnawialnych, jak i nieodnawialnych. Gra łączy zatem tradycyjne poznawanie treści na lekcji z praktycznymi ćwiczeniami, dzięki czemu uczenie się staje się bardziej efektywne. W ramach pakietu opracowywane są także studia przykładowe z życia gospodarczego, pokazujące, jak firmy wiążą w praktyce myślenie biznesowe (nakierowane na efektywność ekonomiczną) z dbałością o środowisko w zakresie wykorzystania źródeł energii. Jest to szczególnie ważne w warunkach polskich, gdzie - jak zauważyli A. Bokwa, P. Jezioro i S. Wypych (2005) - świadomość ekologiczna większości polskiego społeczeństwa jest niewystarczająca, a przyczyn tego stanu rzeczy można się doszukiwać w trudnej sytuacji materialnej wielu rodzin i mentalności odziedziczonej po okresie gospodarki planowej.

Gra może być przydatnym środkiem dydaktycznym dla nauczycieli kilku przedmiotów szkolnych na II i III etapie edukacyjnym. Prowadzanie lekcji szkolnej z wykorzystaniem tego narzędzia odbywa się aktywizującą techniką kształcenia, którą jest gra dydaktyczna. W dydaktyce ogólnej mianem gry dydaktycznej nazywana jest technika pracy w procesie nauczania - uczenia się, w której uczniowie, pracując aktywnie, wykonują kolejno wyznaczone zadania według jasno określonych zasad, dla osiągnięcia zamierzonego celu, a wykonywaniu owych zadań towarzyszą element rywalizacji oraz zaangażowanie emocjonalne uczniów.

Gra PowerPlayer sprzyja łącznej realizacji (scalaniu treściowemu) dwóch ważnych celów kształcenia, którymi są kształtowanie umiejętności i postaw przedsiębiorczych z przekazywaniem treści kształcenia związanych z zagadnieniami ekorozwoju (w tym wykorzystania źródeł energii). Połączenie to może pomagać w kształtowaniu prawidłowych postaw uczniów wobec tych ważnych i jednocześnie skomplikowanych dla nich zagadnień. Scalanie treściowe wskazanych zagadnień utwierdzać będzie uczniów w przekonaniu o konieczności wieloaspektowej analizy zjawisk i będzie uczyć ich spoglądania na trudne zagadnienia z różnych punktów widzenia. Wynika to z faktu, że szczególny nacisk położony jest na problematykę kosztów (a więc w konsekwencji efektywności ekonomicznej przedsiębiorstwa) i skutków społecznych 
oraz środowiskowych wykorzystania poszczególnych odnawialnych i nieodnawialnych źródeł. Pomagać będzie wreszcie w budowaniu holistycznej (złożonej, całościowej i spójnej) wizji świata, którą zaburza sztuczny szkolny podział treści pomiędzy przedmioty szkolne.

Pakiet gry oprócz planszy, kart i instrukcji w pudełku obejmuje także wsparcie dla nauczycieli (przewodnik dla nauczyciela, ulotka informacyjna „szybkiego startu”, arkusz kalkulacyjny do obliczania wyników poszczególnych grup; studia przypadku, materiały dodatkowe, jak prezentacja multimedialna wprowadzająca $\mathrm{w}$ grę) oraz narzędzia wsparcia on-line, m.in. do obliczania wyników poszczególnych rund przez uczniów (także do użytku na tabletach czy smartfonach). W ramach projektu wypracowane zostały także wskazówki do tzw. service learning, których celem jest zaangażowanie uczniów w rozwiązywanie problemów lokalnych społeczności, np. w zakresie oszczędności zużycia energii przez podejmowanie odpowiednich działań itp.

Gra PowerPlayer jest w końcowej fazie przygotowania do udostępnienia, opracowano jej wersję finalną na podstawie przygotowanej wcześniej wersji demonstracyjnej dla celów pilotażowych. Od grudnia 2015 do lutego 2016 r. gra została przetestowana przez nauczycieli w szkołach w całej Europie. Na podstawie ich doświadczenia została opracowana ostateczna wersja gry, która w wersji elektronicznej (do wydruku) dostępna będzie bezpłatnie pod koniec 2016 r. W ramach projektu przeprowadzono także przeszkolenie nauczycieli i studentów studiów nauczycielskich z zakresu jej wykorzystania. Osoby te egzemplarze gry otrzymały w postaci wydrukowanej. Została ona jednak tak zaprojektowana, aby każdy nauczyciel czy trener, który chce z niej skorzystać, mógł ją samodzielnie wydrukować i przygotować do wykorzystania bez specjalistycznych urządzeń, a z wielu elementów wsparcia korzystać w wersji elektronicznej, bez konieczności druku. Powinno to wpłynąć na zwiększenie jej dostępności i szersze wykorzystanie w szkołach.

\section{Wykorzystanie gry PowerPlayer do osiągania celów kształcenia na II i III etapie edukacyjnym}

Gra PowerPlayer służy realizacji ważnych celów kształcenia w zakresie wiedzy, umiejętności i postaw. W tabeli 1 zestawiono kilka najważniejszych efektów kształcenia, które można osiągnąć z wykorzystaniem niniejszej gry.

Gra PowerPlayer znajduje swoje praktyczne zastosowanie w polskiej szkole, głównie na poziomie edukacyjnym ostatniej klasy szkoły podstawowej i w gimnazjum. Służyć może jako narzędzie do realizacji celów kształcenia (treści szczegółowych) zawartych w Podstawie programowej kształcenia ogólnego dla II i III etapu edukacyjnego (Rozporządzenie Ministra Edukacji Narodowej..., 2009). W szkole podstawowej grę można wykorzystać do realizacji wybranych treści kształcenia przedmiotu przyroda. W gimnazjum natomiast zagadnienia związane z tematyką gry (przedsiębiorczością, zrównoważonym rozwojem, odnawialnymi źródłami energii) pojawiają się na lekcjach geografii ${ }^{2}$, biologii i - najliczniej - wiedzy o społeczeństwie (por. analiza podstawy programowej w pracy Rachwał, Kurek, Boguś, 2016). Wykorzystanie gry w gimnazjum umożliwia łączną realizację zagadnień rozproszonych treściowo na różnych przedmiotach szkolnych. Zdaniem autorów, najefektywniejsze byłoby wykorzystanie gry wspólnie, przez kilku nauczycieli przedmiotowych, np. w ramach warsztatów lub pracy

\footnotetext{
${ }^{2}$ Szerzej o związkach programów nauczania przedsiębiorczości i geografii w pracy M. Borowiec i T. Rachwała
} (2011). 
projektowej (obowiązkowej w gimnazjum). W tabeli 2 zestawiono treści kształcenia konieczne do realizacji w obowiązującej Podstawie programowej kształcenia ogólnego, które z powodzeniem zrealizować można, wykorzystując prezentowaną grę.

Tab. 1. Efekty kształcenia możliwe do osiągnięcia z wykorzystaniem gry PowerPlayer

\begin{tabular}{|l|c|l|}
\hline \multicolumn{1}{|c|}{ Wiedza } & \multicolumn{1}{|c|}{ Umiejętności } & \multicolumn{1}{c|}{ Postawy } \\
\hline - Uczeń zna źródła energii & - Uczeń rozwija umiejętność & - Uczeń ma świadomość \\
i i ich podział na odnawialne & myślenia systemowego. & wpływu swojego działania \\
i nieodnawialne. & - Uczeń potrafi podejmować & \multicolumn{1}{c|}{ na stan środowiska. } \\
- Uczeń wie, jaki wpływ & przemyślane decyzje & - Uczeń wie, że obowiązujące \\
na środowisko przyrodnicze & i ponosić ich konsekwencje. & normy społeczne mają \\
ma korzystanie & - Uczeń potrafi planować & wpływ na zrównoważony \\
z poszczególnych źródeł & wydatki, biorąc pod uwagę & rozwój i ochronę \\
energii. & potrzeby i możliwości & środowiska. \\
- Uczeń zna negatywne & finansowe. & - Uczeń wie, że interesy \\
skutki korzystania z energii & - Uczeń potrafi szybko & ekonomiczne często stoją \\
nieodnawialnej. & wykonywać proste & w sprzeczności z zasadami \\
- Uczeń wie, że energia & obliczenia matematyczne. & zrównoważonego rozwoju. \\
z nieodnawialnych źródeł & - Uczeń podnosi swe & - Uczeń jest przekonany, że \\
jest tańsza od energii ze & umiejętności pracy & obok zysku, w działalności \\
źródeł odnawialnych. & w grupie, przyjmując rolę & przedsiębiorstwa równie \\
& lidera lub wykonawcy & ważny jest jego sukces \\
& zadań. & pozaekonomiczny: dobry \\
& & wizerunek, szacunek \\
& & i zaufanie pracowników, \\
& & poszanowanie przyrody. \\
\hline
\end{tabular}

Źródło: opracowanie własne

Tab. 2. Wybrane cele kształcenia (treści szczegółowe) na II i III etapie edukacyjnym możliwe do realizacji przy użyciu gry PowerPlayer

\section{II etap edukacyjny: szkoła podstawowa, klasy IV-VI Przedmiot: PRZYRODA}

5. Człowiek a środowisko. Uczeń:

2) wyjaśnia wpływ codziennych zachowań w domu, w szkole, w miejscu zabawy na stan środowiska;

3) proponuje działania sprzyjające środowisku przyrodniczemu;

4) podaje przykłady miejsc w najbliższym otoczeniu, w których zaszły korzystne i niekorzystne zmiany pod wpływem działalności człowieka.

10. Zjawiska elektryczne i magnetyczne w przyrodzie. Uczeń:

3) wymienia źródła prądu elektrycznego i dobiera je do odbiorników, uwzględniając napięcie elektryczne;

6) uzasadnia potrzebę i podaje sposoby oszczędzania energii elektrycznej.

\section{III etap edukacyjny: gimnazjum}

Przedmiot: WIEDZA O SPOŁECZEŃSTWIE

1. Podstawowe umiejętności życia w grupie. Uczeń: 1) omawia i stosuje zasady komunikowania się i współpracy w grupie (np. bierze udział w dyskusji, zebraniu, wspólnym działaniu); 2) wymienia i stosuje podstawowe sposoby podejmowania wspólnych decyzji; 3) przedstawia i stosuje podstawowe sposoby rozwiązywania konfliktów w grupie i między grupami; 
23. Problemy współczesnego świata. Uczeń: 4) rozważa, jak jego zachowania mogą wpływać na życie innych ludzi na świecie (np. oszczędzanie wody i energii, przemyślane zakupy);

24. Praca i przedsiębiorczość. Uczeń: 1) wyjaśnia na przykładach z życia własnej rodziny, miejscowości i całego kraju, w jaki sposób praca i przedsiębiorczość pomagają w zaspokajaniu potrzeb ekonomicznych; 2) przedstawia cechy i umiejętności człowieka przedsiębiorczego; bierze udział w przedsięwzięciach społecznych, które pozwalają je rozwinąć; 3) stosuje w praktyce podstawowe zasady organizacji pracy (ustalenie celu, planowanie, podział zadań, harmonogram, ocena efektów).

25. Gospodarka rynkowa. Uczeń: 2) podaje przykłady racjonalnego i nieracjonalnego gospodarowania; stosuje zasady racjonalnego gospodarowania w odniesieniu do własnych zasobów (np. czasu, pieniędzy); 3) charakteryzuje gospodarkę rynkową (prywatna własność, swoboda gospodarowania, konkurencja, dążenie do zysku, przedsiębiorczość);

26. Gospodarstwo domowe. Uczeń: 3) przygotowuje budżet konkretnego przedsięwzięcia z życia ucznia, klasy, szkoły; rozważa wydatki i źródła ich finansowania;

31. Etyka w życiu gospodarczym. Uczeń: 1) przedstawia zasady etyczne, którymi powinni się kierować pracownicy i pracodawcy; wyjaśnia, na czym polega społeczna odpowiedzialność biznesu.

\section{III etap edukacyjny: gimnazjum przedmiot: GEOGRAFIA}

4. Położenie i środowisko przyrodnicze Polski. Uczeń: 5) Wymienia główne rodzaje zasobów naturalnych Polski i własnego regionu: lasów, wód, gleb, surowców mineralnych; korzystając z mapy opisuje ich rozmieszczenie i określa znaczenie gospodarcze.

\section{III etap edukacyjny: gimnazjum} Przedmiot: BIOLOGIA

10. Globalne i lokalne problemy środowiska. Uczeń: 3. Proponuje działania ograniczające zużycie wody i energii elektrycznej oraz wytwarzanie odpadów w gospodarstwach domowych.

Źródło: opracowanie własne na podstawie Podstawy programowej kształcenia ogólnego (Rozporządzenie Ministra Edukacji Narodowej... 2009)

\section{Podstawowe założenia scenariusza gry PowerPlayer}

Podstawowym celem graczy jest zapewnienie firmie określonej ilości energii przy jednoczesnym uwzględnieniu ograniczeń budżetowych oraz założeń czy zadań wyznaczonych w ramach poszczególnych rund (wytyczne zależne od profilu firmy). Materiały do gry to: karty profili firm, karty rund i karty specjalne ekoakcji.

Gra trwa 4 rundy, każda wg struktury: otwarcie $(5 \mathrm{~min})$, poszukiwanie rozwiązania (20 min), zliczenie punktów, określenie zwycięzcy rundy - podsumowanie (łącznie ok. 1 godziny lekcyjnej na rundę, bez szerszego wprowadzenia w problematykę).

Grupy, składające się z od 3 do 6 uczniów, reprezentują firmy odzieżowe, zlokalizowane w fikcyjnym regionie WattLand, w którym dostępne są dla nich wszystkie podstawowe źródła energii, zarówno odnawialne (energia wiatru, wodna, słoneczna, biomasy), jak i nieodnawialne (węgiel, gaz, ropa, energia atomowa). Firmy (łącznie 5) zróżnicowane są ze względu na profil działalności. Każda runda to nowe wyzwania dla firm. W trakcie gry wykorzystuje się tablicę gry do podejmowania decyzji biznesowych, karty rund, karty specjalnych ekoakcji (w 3 i 4 rundzie), arkusze wyników oraz telefon, tablet lub komputer do wykorzystania pomocnika on-line, dzięki któremu uczniowie mogą samodzielnie podliczyć wyniki poszczególnych rund dla swojej grupy. Dzięki specjalnemu arkuszowi kalkulacyjnemu nie ma jednak konieczności jego stosowania - nauczyciel może sam wyliczyć wyniki dla poszczególnych grup. Zasadniczym celem gry jest podejmowanie decyzji biznesowych o zakupie energii z różnych 
źródeł (realizacja celu zakupowego przy określonych, ograniczonych środkach finansowych, zapisanego na karcie danej rundy) przy uwzględnieniu efektów środowiskowych oraz wpływu tych decyzji na reputację firmy i zadowolenie pracowników. Ocena punktowa jest więc wypadkową nie tylko kosztów zakupu, ale także pozostałych 3 parametrów, tj. wyników w zakresie wpływu na środowisko, reputację i zadowolenie. W 3 i 4 rundzie uczniowie mogą użyć kart specjalnych, podejmując tzw. ekoakcje, np. polegające na inwestycji w bardziej energooszczędne urządzenia. Zwycięzcą gry zostaje grupa, która zgromadziła najwięcej punktów, obliczanych po każdej rundzie, w zależności od wyników podejmowanych decyzji zakupowych oraz premii za określone osiągniecia i działania specjalne.

\section{Opinie nauczycieli i uczniów testujących pilotażowo grę}

Choć proces wdrożenia testowego gry rozpoczął się pod koniec 2015 r. i zakończył we wszystkich krajach w I kwartale 2016 r., to na podstawie wyników badań opinii nauczycieli ze szkół polskich ${ }^{3}$ można przyjąć, że gra jest ciekawa i stosunkowo atrakcyjna dla uczniów, aczkolwiek należy podkreślić, że uczniowie młodsi, z ostatniej klasy szkoły podstawowej, zainteresowani byli głównie zdobyciem jak największej liczby punktów (traktując grę głównie jako pewną rywalizację), aspekty merytoryczne odnoszące się do zachowań przedsiębiorczych i spraw związanych z ekorozwojem mniej ich interesowały, natomiast uczniowie gimnazjum byli bardziej zainteresowani merytoryczną stroną gry. Dla uczniów szkoły podstawowej gra była bardziej skomplikowana, ale nie stanowiło to bariery w jej użyciu na lekcjach. Nauczyciele zwracali też uwagę na pewne techniczne problemy z użyciem arkusza kalkulacyjnego do obliczeń punktów i kalkulatora wyników on-line oraz postulowali przygotowanie bardziej dogłębnego wyjaśnienia mechanizmu liczenia punktów. Uwagi te zostały uwzględnione w finalnej wersji gry. Natomiast uczniowie pytani o plusy i minusy gry wskazali przede wszystkim na fakt, że podobała się im oprawa graficzna gry (głównie planszy oraz wykorzystywanych w grze fasolek). Zwrócili również uwagę, że gra sprzyja rozwijaniu umiejętności logicznego myślenia/planowania oraz dysponowania funduszami, uczy ich pracy w grupach i rozwija umiejętności rachunkowe dzięki częstym obliczeniom matematycznym. Część uczniów uważała, że powinno być więcej rund gry oraz więcej możliwości inwestowania (tj. użycia tzw. ekoakcji). Zastrzeżenia wzbudzał niejasny dla nich do końca sposób obliczania punktów na koniec rundy. Sprawa ta była przedmiotem dalszych prac i dyskusji w zespole projektowym, gdyż pokazanie precyzyjne algorytmu obliczeń uczniom może spowodować, że nie będą oni prowadzić merytorycznych dyskusji nad decyzjami biznesowymi w zakresie zakupu energii, a jedynie skupiać się na takim doborze struktury zakupów, żeby podstawiając do wzoru, uzyskać jak najlepszy efekt punktowy. W efekcie dyskusji uznano, że takie szczegółowe wyjaśnienia powinien znać tylko nauczyciel (zostało to przekazane w podręczniku nauczyciela) i to on, znając lepiej swoją grupę uczniów, powinien decydować, w jakiej szczegółowości przekazać im informacje nt. algorytmu obliczania punktów. Za ważny element gry uznano możliwość prowadzenia dyskusji w klasie nad podejmowanymi decyzjami i ich skutkami, zarówno dla wyniku punktowego, jak i skutkami dla firmy, społeczności (interesariuszy firmy) i środowiska przyrodniczego, gdyby takie decyzje były podejmowane realnie w rzeczywistości gospodarczej, a nie symulowane w grze. Badania

${ }^{3} \mathrm{~W}$ trakcie przygotowywania ostatecznej wersji artykułu do druku wyniki badań w innych krajach były jeszcze opracowywane. 
ankietowe wśród uczniów wskazały także na pozytywny wpływ gry na wzrost wiedzy i umiejętności w zakresie problematyki przedsiębiorczości oraz wykorzystania różnych źródeł energii.

Z finalną wersją gry i możliwością jej zastosowania w praktyce szkolnej wraz z pakietem materiałów dodatkowych mogli się zapoznać także nauczyciele oraz studenci studiów nauczycielskich w ramach specjalnych warsztatów szkoleniowych. Dokonali oni oceny gry (na ankiety prowadzone w systemie elektronicznym odpowiedziały 23 osoby z 53 uczestniczących w szkoleniu, w tym 10 studentów i 13 nauczycieli. Na pytanie o to, czy gra podniesie znajomość problematyki zrównoważonego podejścia do zużycia energii, ponad 90\% respondentów odpowiedziało pozytywnie, tj. że zgadzają się z tym stanowiskiem. Podobnie $100 \%$ respondentów zgodziło się ze stwierdzeniem, że gra wpłynie na podniesienie poziomu myślenia przedsiębiorczego uczniów, a także, że gra jest atrakcyjna i motywująca dla uczniów. W nieco mniejszym stopniu (ok. 75\% nauczycieli i 90\% studentów) respondenci zgadzają się ze stwierdzeniem zawartym w ankiecie, że gra wpłynie na większą chęć zaangażowania społecznego uczniów. Wynikać to może jednak z faktu, że respondenci nie mogli w praktyce zastosować w szkole propozycji w zakresie zadań dodatkowych, związanych z pracą na rzecz społeczności. Wszyscy lub niemal wszyscy respondenci zgodzili się ze stwierdzeniami, że projekt gry jest atrakcyjny dla uczniów, pakiet dla nauczyciela jest dobrze opracowany do wsparcia go w użyciu gry w klasie, a także, iż zamierzają w przyszłości wykorzystywać grę w praktyce szkolnej, gdyż uważają użycie gier za bardziej efektywne w osiąganiu celów kształcenia.

\section{Zakończenie}

Wykorzystanie gry i związanego z nią pakietu materiałów dydaktycznych pozwala na uatrakcyjnienie nauczania oraz powiązanie kształtowania postaw przedsiębiorczych z postawami proekologicznymi, co w dobie współczesnych wyzwań cywilizacyjnych jest bardzo istotne. Pakiet stanowi wsparcie nauczycieli w przekazywaniu wiedzy i kształceniu umiejętności z zakresu przedsiębiorczości oraz zasad ekorozwoju w przystępny i atrakcyjny sposób. Dzięki temu zwiększa się stopień wykorzystania aktywizujących metod kształcenia.

Jak wskazują wyniki analizy podstawy programowej, gra daje możliwość łączenia treści kształcenia z różnych przedmiotów (w gimnazjum: głównie WOS, geografia, biologia), a przez to nawiązania współpracy przez nauczycieli oraz przyczynia się do kompleksowego rozumienia zjawisk przez uczniów. W szkole podstawowej oprócz przedmiotu przyroda istnieje możliwość jej wykorzystania także na lekcjach wychowawczych oraz różnego typu kółkach zainteresowań.

Dzięki wykorzystaniu gry następuje przeniesienie nacisku w ramach kształcenia z nauczania na proces uczenia się - samodzielnego dochodzenia przez uczniów do wiedzy i umiejętności oraz kształtuje się umiejętność podejmowania decyzji i rozumienia ich skutków ekonomicznych (dla firmy), a także społecznych (dla pracowników, otoczenia, w tym środowiska przyrodniczego). Wydaje się więc, że przedstawiona propozycja może przyczynić się do podniesienia efektywności i jakości edukacji w zakresie przedsiębiorczości, przygotowując uczniów do zakładania i prowadzenia własnych firm bądź pracy w innych przedsiębiorstwach czy instytucjach w respekcie dla zasad ekorozwoju. Wskazują na to wyniki badań uczniów uczestniczących w pilotażu gry oraz nauczycieli, zarówno testujących grę, jak i poznających ją na warsztatach, a także studentów studiów nauczycielskich. 
Literatura

References

Bernatowicz, A., Rataj, Z. (2015). Wsparcie procesu dydaktycznego grami planszowymi na przykładzie gry „Społeczność w działaniu”. Studia Oeconomica Posnaniensia, 3(5), 104-119.

Bokwa, A., Jezioro, P., Wypych, S. (2005). Sustainable Development, Ecological Awareness and Geographical Education, Prace Geograficzne/Instytut Geografii $i$ Gospodarki Przestrzennej Uniwersytetu Jagiellońskiego, 115, 59-66.

Bołtuć, M., Bołtuć P. (2004). Inne spojrzenie na nauczanie w oparciu o gry. e-mentor, 2(4). Pozyskano z: http://www.e-mentor.edu.pl/artykul/index/numer/4/id/43

Borowiec, M., Rachwał, T. (2011). Kształtowanie postaw przedsiębiorczych na lekcjach geografii wyzwaniem edukacyjnym w procesach globalizacji. Przedsiębiorczość - Edukacja, 7, 321-332.

Cewińska, J., Krasnova, A. (2014). Grywalizacja w rozwoju i edukacji - szanse i zagrożenia. Prace Naukowe Uniwersytetu Ekonomicznego we Wrocławiu, 350, 73-81.

Gaweł, A., Pietrzykowski M., (2014). The Strategic Management Virtual Game Method in Business Education, Wydawnictwo IUSatTAX, Warszawa.

Gaweł, A. (2014). Gry strategiczne w edukacji przedsiębiorczej. Horyzonty Wychowania, 13(26), 303-325.

Markowski, A., Pietralczyk, Ł. (2013). Gry ekonomiczne i ich wykorzystanie - wybrane przykłady. Prace Naukowe Młodych Ekonomistów Wyższej Szkoły Bankowej w Gdańsku, 2, 139-148.

Pivec, M., Dziabenko, O. (2004). Model gry edukacyjnej dla potrzeb kształcenia online grup studenckich. e-mentor, 2(4). Pozyskano z: http://www.e-mentor.edu.pl/artykul/index/numer/4/id/42

Rachwał, T., Kurek, S., Boguś, M. (2016). Entrepreneurship Education at Secondary Level in Transition Economies: A Case of Poland. Entrepreneurial Business and Economics Review, 4(1), 61-81. DOI: http://dx.doi.org/10.15678/EBER.2016.040105

Rozporzadzenie Ministra Edukacji Narodowej z dnia 23 grudnia 2008 r. w sprawie podstawy programowej wychowania przedszkolnego oraz kształcenia ogólnego w poszczególnych typach szkół, Dz.U. z dn.15 stycznia 2009 r. rr 4, poz. 17.

Rzepka, B. (2014). Strategiczne gry planszowe. Personel i Zarządzanie, 2014(1), 72-75.

Škudienè V., 2012, Edukacja oparta na studium przypadku. W: Ph. Ammerman, A. Gaweł, M. Pietrzykowski, R. Rauktiené, T. Williamson (red.), Metoda studium przypadku w edukacji biznesowej, Warszawa: Wydawnictwo IUSatTAX.

Szmulczyńska B., 2007, E-learning - oferta edukacyjna również dla szkół. W: P. Wachowiak, M. Dąbrowski, B. Majewski (red.), Kształtowanie postaw przedsiębiorczych a edukacja ekonomiczna, Warszawa: Fundacja Promocji i Akredytacji Kierunków Ekonomicznych.

Tracz, M., Rachwał, T. (2008). Metody nauczania i środki dydaktyczne stosowane przez nauczycieli podstaw przedsiębiorczości - wyniki badań. Przedsiębiorczość - Edukacja, 4, 325-330.

Wach, K. (2013). Edukacja na rzecz przedsiębiorczości wobec współczesnych wyzwań cywilizacyjno-gospodarczych. Przedsiębiorczość - Edukacja, 9, 246-257.

Zioło, Z. (2012). Miejsce przedsiębiorczości w edukacji. Przedsiębiorczość - Edukacja, 8, 10-23.

Żur, A. (2014). Exploring the Role of Inspiration in Entrepreneurship Education. Horyzonty Wychowania, 13(26), 179-194.

Wioletta Kilar, dr, Uniwersytet Pedagogiczny im. Komisji Edukacji Narodowej w Krakowie, Instytut Geografii, Zakład Przedsiębiorczości i Gospodarki Przestrzennej. Geograf ekonomiczny. Adiunkt w Zakładzie Przedsiębiorczości i Gospodarki Przestrzennej Instytutu Geografii Uniwersytetu Pedagogicznego w Krakowie, Sekretarz Rady Redakcyjnej czasopisma „Prace Komisji Geografii Przemysłu Polskiego Towarzystwa Geograficznego". Posiada znaczne doświadczenie jako nauczyciel geografii i podstaw przedsiębiorczości, które zdobyła, pracując w kilku ponadgimnazjalnych szkołach krakowskich. Jej zainteresowania badawcze ukierunkowane są przede wszystkim na procesy kształtowania się i funkcjonowania ponadnarodowych korporacji, globalizacji, przemian struktur przestrzennych przemysłu oraz problematykę nauczania przedsiębiorczości i geografii w szkole. Jest autorem i współautorem licznych 
publikacji z zakresu geografii społeczno-ekonomicznej i przedsiębiorczości oraz podręcznika, wielu materiałów dydaktycznych, edukacyjnych i ekspertyz.

Wioletta Kilar, PhD, Pedagogical University of Cracow, Institute of Geography, Department of Entrepreneurship and Spatial Management. An economic geographer. A lecturer in the Department of Entrepreneurship and Spatial Management at the Institute of Geography of the Pedagogical University of Cracow. Secretary of the Editorial Board of the Studies of the Industrial Geography Commission of the Polish Geographical Society. She has a considerable experience as a teacher of geography and basics of entrepreneurship, having worked in several secondary schools in Krakow. Her research interests are focused primarily on the processes of formation and operation of multinational corporations, globalization, transformation of spatial structures of industry and the issues of entrepreneurship education issues and geography at school. She is the author of numerous publications in socio-economic geography and entrepreneurship, and many teaching and educational materials and expertises.

Sławomir Kurek, dr hab., profesor Uniwersytetu Pedagogicznego, Uniwersytet Pedagogiczny im. Komisji Edukacji Narodowej w Krakowie, Instytut Geografii, Zakład Geografii Społeczno-Ekonomicznej. Geograf społeczno-ekonomiczny. Członek Komitetu Nauk Demograficznych PAN. Pełni m.in. funkcję zastępcy dyrektora Instytutu Geografii ds. Nauki i Współpracy Zagranicznej, kierownika studiów doktoranckich z geografii oraz redaktora naczelnego czasopisma „Annales Universitatis Paedagogicae Cracoviensis, Studia Geographica”. Jego zainteresowania badawcze skupiają się przede wszystkim na problematyce przemian struktur społeczno-demograficznych Polski i Europy, procesów suburbanizacji w obszarach metropolitalnych oraz edukacji w zakresie przedsiębiorczości.

Sławomir Kurek, PhD, associate professor at the Pedagogical University of Cracow, Institute of Geography, Department of Socio-Economic Geography. A socio-economic geographer. Member of the Committee on Demographic Studies of the Polish Academy of Sciences. He is, among other activities, the Deputy Head for Research and International Relations of Institute of Geography, Head of Doctoral Studies in geography at the Pedagogical University, and Editor in Chief of Annales Universitatis Paedagogicae Cracoviensis, Studia Geographica. Research interests focus primarily on the issue of changes of the socio-demographic structures in Poland and Europe, suburbanisation processes in metropolitan areas, as well as entrepreneurship education.

Tomasz Rachwal, dr, Uniwersytet Pedagogiczny im. Komisji Edukacji Narodowej w Krakowie, Instytut Geografii, Zakład Przedsiębiorczości i Gospodarki Przestrzennej. Kierownik Zakładu Przedsiębiorczości i Gospodarki Przestrzennej Instytutu Geografii Uniwersytetu Pedagogicznego w Krakowie, pełni m.in. funkcje: Sekretarza Naukowego Komisji Geografii Przemysłu Polskiego Towarzystwa Geograficznego, zastępcy Redaktora Naczelnego czasopism: „Przedsiębiorczość - Edukacja”, „Prace Komisji Geografii Przemysłu Polskiego Towarzystwa Geograficznego”, „Annales Universitatis Paedagogicae Cracoviensis Studia Geographica” oraz członka redakcji „Entrepreneurial Business and Economics Review”. Autor lub współautor podręczników szkolnych i akademickich z zakresu geografii ekonomicznej i przedsiębiorczości. Jego zainteresowania badawcze skupiają się przede wszystkim na problematyce przemian struktur przestrzennych przemysłu, funkcjonowania różnych branż działalności gospodarczej, restrukturyzacji przedsiębiorstw oraz roli przedsiębiorczości w rozwoju układów przestrzennych, a także edukacji w zakresie przedsiębiorczości.

Tomasz Rachwal, PhD, Pedagogical University of Cracow, Institute of Geography, Department of Entrepreneurship and Spatial Management. A head of the Department of Entrepreneurship and Spatial Management of Institute of Geography of the Pedagogical University of Cracow, a Scientific Secretary of the Industrial Geography Committee of the Polish Geographical Society, A Deputy Editor in Chief of the following journals: Entrepreneurship - Education, Studies of the Industrial Geography Commission of the Polish Geographical Society, Annales Universitatis Paedagogicae Cracoviensis Studies Geographica, and a member of the editorial board of Entrepreneurial Business and Economics Review. The author or co-author of school and academic textbooks on economic geography and entrepreneurship. His research interests focus primarily on the issue of change of spatial structures of industry, the functioning 
of various branches of industrial activity, corporate restructuring and the role of entrepreneurship in the development of spatial systems as well as entrepreneurship education.

Marcin Semczuk, mgr, Uniwersytet Pedagogiczny im. Komisji Edukacji Narodowej w Krakowie, Instytut Geografii, Zakład Przedsiębiorczości i Gospodarki Przestrzennej. Asystent i doktorant w Zakładzie Przedsiębiorczości i Gospodarki Przestrzennej Instytutu Geografii Uniwersytetu Pedagogicznego w Krakowie, pełni m.in. funkcje Sekretarza redakcji „Przedsiębiorczość - Edukacja” ds. baz online czasopism oraz sekretarza cyklicznych konferencji z zakresu przedsiębiorczości organizowanych co roku w Krakowie. Jego zainteresowania badawcze skupiają się przede wszystkim na problematyce rozwoju społecznogospodarczego układów lokalnych a także edukacji w zakresie przedsiębiorczości.

Marcin Semczuk, M.A., Pedagogical University of Cracow, Institute of Geography, Department of Entrepreneurship and Spatial Management. An assistant and PhD student at the Department of Entrepreneurship and Spatial Management of Institute of Geography of the Pedagogical University of Cracow, a Secretary of the Editorial Board of "Entrepreneurship - Education" journal and secretary of annual conferences on entrepreneurship. His research interests focus primarily on the socio-economic development of local systems and entrepreneurship education.

Agnieszka Świętek, dr, Uniwersytet Pedagogiczny im. Komisji Edukacji Narodowej w Krakowie, Instytut Geografii, Zakład Dydaktyki Geografii. Doktor nauk o Ziemi w zakresie geografii, Absolwentka studiów z zakresu geografii Uniwersytetu Pedagogicznego w Krakowie w specjalności Przedsiębiorczość i gospodarka przestrzenna. Adiunkt w Instytucie Geografii Uniwersytetu Pedagogicznego w Krakowie. Jej zainteresowania badawcze skupiają się wokół dwóch tematów: problematyki edukacji z zakresu geografii i przedsiębiorczości, a w szczególności procesu zakładania własnej działalności gospodarczej, wchodzenia młodych ludzi na rynek pracy oraz poziomu życia Romów w Polsce.

Agnieszka Świętek, PhD in geography, graduated from the Pedagogical University in Cracow MA degree in geography, specialization in Entrepreneurship and spatial planning. Adjunct (asssoc. professor) at the Pedagogical University of Cracow, Institute of Geography. Her research interests focus on two different research themes: the education in the field of geography and entrepreneurship, in particular the process of starting up own business, young people entering into the labor market and the quality of life of the Roma in Poland.

\section{Adres/Adress:}

Uniwersytet Pedagogiczny im. Komisji Edukacji Narodowej w Krakowie

Instytut Geografii

Zakład Przedsiębiorczości i Gospodarki Przestrzennej (W. Kilar, T. Rachwał, M. Semczuk)

Zakład Geografii Społeczno-Ekonomicznej (S. Kurek)

Zakład Dydaktyki Geografii (A. Świętek)

ul. Podchorążych 2

30-084 Kraków, Polska

e-mail: W.Kilar@up.krakow.pl (W. Kilar),sgkurek@up.krakow.pl (S.Kurek), T.Rachwal@up.krakow.pl (T. Rachwał), semczuk@up.krakow.pl (M. Semczuk), swietekaga@wp.pl (A. Świętek)

Publikacja powstała w ramach projektu „Sustainable Entrepreneurship - A Game-Based Exploration for Lower Secondary Schools (SUSEN)", realizowanego przy wsparciu finansowym Komisji Europejskiej w ramach Programu „Erasmust”.

Publikacja odzwierciedla jedynie stanowisko jej autorów i Komisja Europejska oraz Narodowa Agencja Programu Erasmus+ nie ponoszą odpowiedzialności za umieszczoną w niej zawartość merytoryczną.

Informacja o projekcie i grze PowerPlayer: www.powerplayer.info
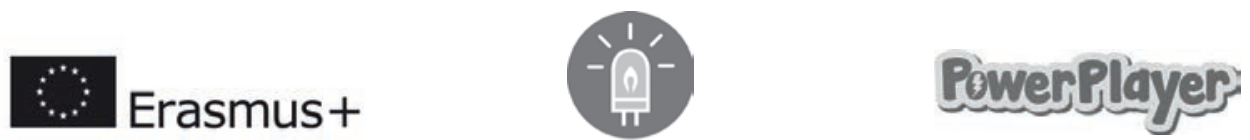